\title{
IsSue of Critical Parts Marking in THE Field of Precise Metrology
}

\author{
Martin Melichar, Jan Kutlwašer \& Nikola Skřivanová
}
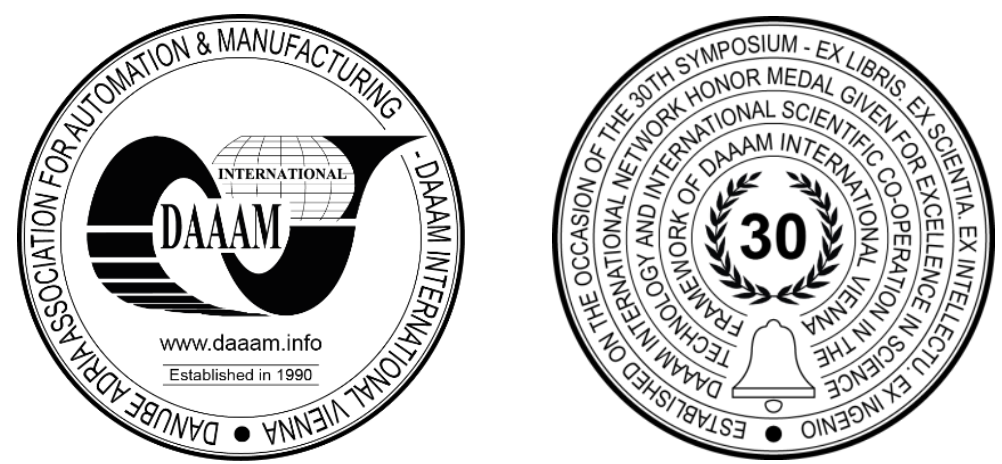

This Publication has to be referred as: Melichar, M[artin]; Kutlwaser, J[an] \& Skrivanova, N[ikola] (2021). Issue of Critical Parts Marking in the Field of Precise Metrology, Proceedings of the 32nd DAAAM International Symposium, pp.0106-0109, B. Katalinic (Ed.), Published by DAAAM International, ISBN 978-3-902734-33-4, ISSN 1726-9679, Vienna, Austria

DOI: $10.2507 / 32$ nd.daaam.proceedings.015

\begin{abstract}
In the field of higher quality management systems, such as automotive IATF 16949, aeronautics EN9100 or railway standards IRIS, unambiguous identification throughout the production process is one of the fundamental principles on which production philosophies are based. This paper deals with an attempt to influence the measurement results of a reference piece using different marking methods. Parameters were evaluated under the same environmental conditions of an accredited laboratory for the 4 tracers, and are thus suitable for statistical comparison. To understand the process and its limitations, an analysis of the measurement system $(\mathrm{Cg} / \mathrm{Cgk})$ was performed and a clear limit was established beyond which single-label methods are no longer applicable.
\end{abstract}

Keywords: Metrology; Traceability; Identification; Marking

\section{Introduction}

Regarding higher quality management systems, such as the automotive IATF 16949, aviation EN9100 or railway ISO/TS 22163:2017 standards, unambiguous identification throughout the production process is one of the basic principles on which production philosophies are based. For example, aviation standard EN9100:2018 in clause 8.4.2 Identification and traceability literally states that "The organisation shall control the unique identification of the outputs when traceability is a requirement, and shall retain the documented information necessary to enable traceability." Finished products are most often identified by a code, enabling traceability often back to the specific melt of the semi-finished material and material inputs. For obvious reasons, this code is only assigned to the product after the final release of the product towards the customer and after verification that the product meets the specifications defined in the technical documentation. [1], [2]. This presents manufacturing companies with a difficult dilemma - how to appropriately identify and temporarily identify parts during production. [3]

a) Products with loss of identification can be treated as non-conforming products according to higher standards with all the consequences until the contrary is clearly proven. This is a requirement that the marking be of sufficient quality and durability

b) The marking must not affect or distort the characteristics of the products and intermediate products 


\section{Experimental analysis}

Within the accredited metrology laboratory L-1718 of the Regional Institute of Technology at the Faculty of Mechanical Engineering, University of West Bohemia in Pilsen, a comprehensive analysis was carried out to investigate the influence of commonly used markers and markers on the outputs of high-precision shape using a Taylor Hobson Talyrond $585 \mathrm{~L}$ device. All measurements were subject to DIN ISO 1101 environmental conditions, i.e. a temperature of $20^{\circ} \mathrm{C} \pm 1{ }^{\circ} \mathrm{C}$ in a vibration-neutral environment, a filter of 15 waves/circumference LSC or $2.5 \mathrm{~mm} \mathrm{LSS}, 5 \mathrm{rpm}$ or $5 \mathrm{~mm} / \mathrm{s}$ and a standard scanning arm with a $3 \mathrm{~mm}$ diameter ball. [7], [8]

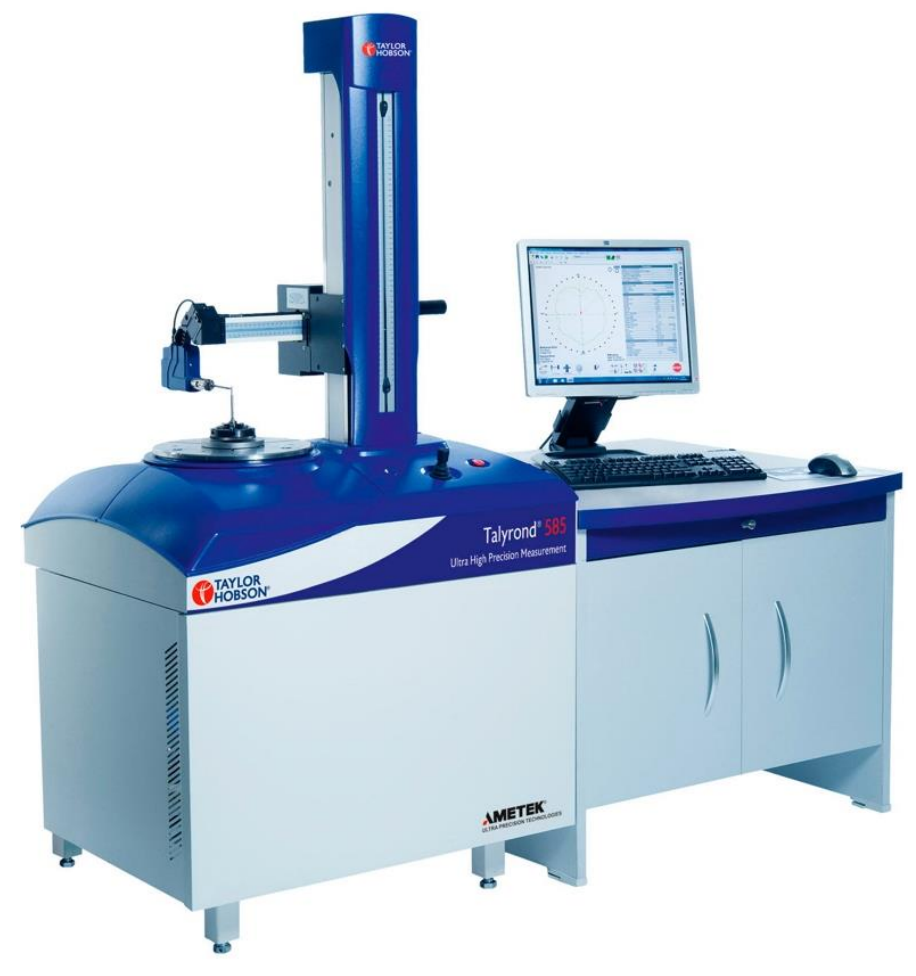

Fig. 1. Talyrond $585 \mathrm{Lt}$

A precision polished standard a cylinder with a diameter and height of $50 \mathrm{~mm}$ was chosen as the test body. This etalon was first tempered in the laboratory to ambient temperature for 12 hours and then carefully cleaned using an ultrasonic cleaner by machine and then manually cleaned using isopropyl alcohol. [5], [6]
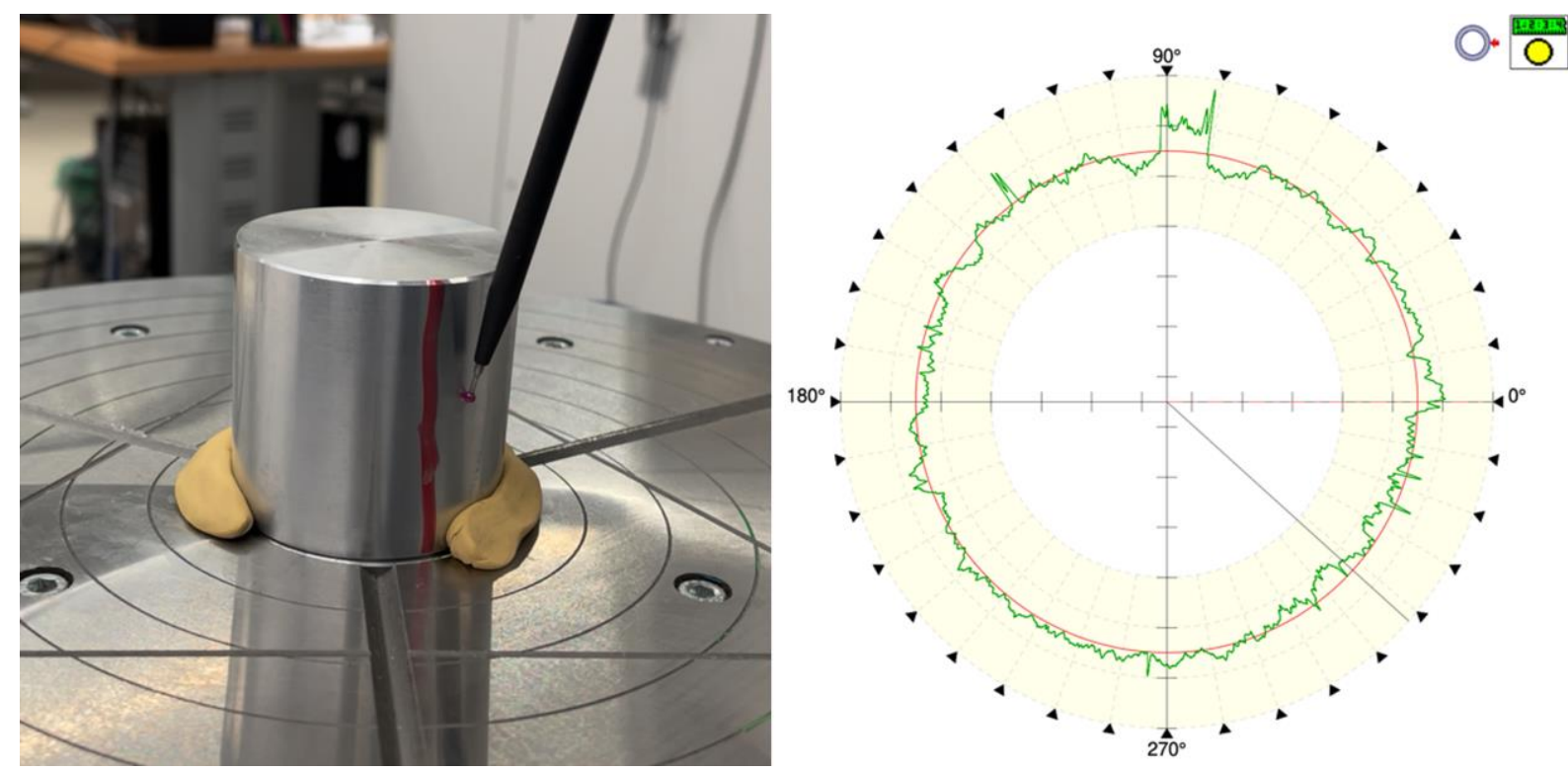

Fig. 2 Marker line evaluation 


\section{Marker layer analysis results}

As part of the statistical verification of the results, the individual experiments were repeated at least 25 times and the resulting data were used to verify the normality of the results and to determine the mean or standard deviation of the results. [4]

- Green colour alcohol marker for DVD KORES $\quad \Rightarrow 1 \mu \mathrm{m}$

- Industrial lacquer MARKER 9100 by Centropen $\quad \Rightarrow 3 \mu \mathrm{m}$

- Thin lacquer marker Paint marker $\quad \Rightarrow 2 \mu \mathrm{m}$

- Red WHITEBOARD marker Centropen $\quad \Rightarrow$ beyond the machine's resolution

a) Following the standard definition of $\mathrm{Cg} / \mathrm{Cgk}$ meter eligibility according to IATF 16949 , namely that a gauge or etalon is only eligible if it is 20 times more accurate than the identified parameter, it is then conventionally correct and acceptable within the supply chain to use verified marking methods in downstream cases:

Prescribed technical specification values:

- Green colour alcohol marker for DVD KORES $\quad \Rightarrow 0,02 \mathrm{~mm}$

- Industrial lacquer MARKER 9100 by Centropen $\quad \Rightarrow 0,06 \mathrm{~mm}$

- Thin lacquer marker Paint marker $\quad=>0,04 \mathrm{~mm}$

- Red WHITEBOARD marker Centropen $\quad \Rightarrow$ an inconclusive result

b) Following the standard definition of the so-called "golden rule of metrology", namely that a gauge or etalon is only eligible if it is 10 times more accurate than the identified parameter, it is then conventionally correct and acceptable within the supply chain to use verified marking methods in downstream cases:

- Green colour alcohol marker for DVD KORES $\quad \Rightarrow 0,01 \mathrm{~mm}$

- Industrial lacquer MARKER 9100 by Centropen $\quad \Rightarrow 0,03 \mathrm{~mm}$

- Thin lacquer Paint marker $\quad=>0,02 \mathrm{~mm}$

- Red WHITEBOARD marker Centropen $\quad \Rightarrow$ beyond the machine's resolution

\section{Result confirmation}

Finally, due to the focus of this article on the aerospace and automotive industry, the VDA5 methodology was chosen as the evaluation methodology. Considering the lengthy calculations and the need for a considerable amount of data (MSA I + II analysis was also performed as part of the validation calculations), the supporting tool Yarvyn was used.

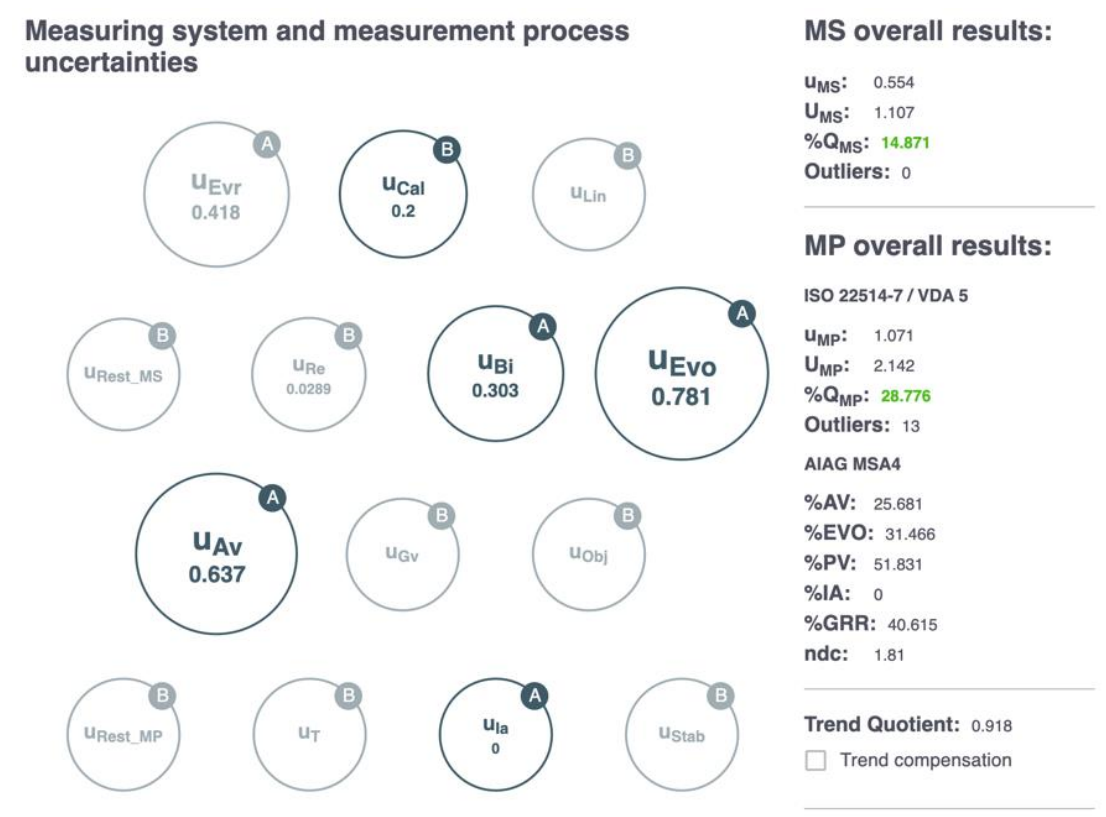

Fig. 3. Yarvyn output with marked uncertainties of interest

In the case of the variants: green alcohol marker / MARKER 9100 / thin varnish marker - the influence and experimentally verified substantial increase of the A-type uncertainty components, namely: uEvo, uBias, uCal, uAv, has been unequivocally proven, thus leading to the degradation of the entire measuring system, including its accuracy, which drops by up to 3 orders of magnitude. [10], [9] 


\section{Conclusion}

The motivation for this document was to consider the effectiveness of the growing trend of $100 \%$ identification in relation to measurement accuracy. Researchers in an accredited laboratory have addressed the question of how the commonly used method of marking products can affect the reliability of dimensional inspection results and thus the inspection itself. A standard $50 \mathrm{~mm}$ diameter standard cylinder was chosen as the test object. To obtain reliable results, it was first necessary to obtain data from a real inspection. Statistically processed data from repeated roundness measurements on a high precision Taylor Hobson roundness tester were used. The parameters were measured under the same environmental conditions for 4 different commonly used markers. Due to the identical input conditions, it was also possible to compare the data afterwards. In order to understand the process and its limitations, an analysis of the measurement system was carried out according to the VDA5 methodology and an evaluation of the individual effects on the uB type uncertainty and thus on the overall uc uncertainty. As can be seen from the results at a glance, an inappropriate way of marking a part before inspection can degrade the reliability of the measurement by hundreds of percent. This was most evident in the Marker 9100, where the measurement uncertainty increased to an extreme. This article is part of a comprehensive study of the effect of the human factor on the accuracy and reliability of results. The individual subexperiments performed in 2021 and planned for 2022 will be published in a comprehensive method manual on shop-floor metrology.

\section{Acknowledgments}

The article contribution has been prepared under project SGS-2019-008

\section{References}

[1] Svingerova, M. \& Melichar, (2017). Evaluation of Process Risks in Industry 4.0 Environment, Proceedings of the 28th DAAAM International Symposium, pp.1021-1029, B. Katalinic (Ed.), Published by DAAAM International, ISBN 978-3-902734-11-2, ISSN 1726-9679, Vienna, Austria DOI: 10.2507/28th.daaam.proceedings. 142

[2] Banduka, N.; Macuzic, I.; Stojkic, Z.; Bosnjak, I. \& Peronja, I. (2016). Using 80/20 Principle to Improve Decision Making at PFMEA, Proceedings of the 27th DAAAM International Symposium, pp.0487-0492, B. Katalinic (Ed.), Published by DAAAM International, ISBN 978-3-902734- 08-2, ISSN 1726-9679, Vienna, Austria DOI: 10.2507/27th.daaam.proceedings.073

[3] Markova, P.; Prajova, V.; Homokyova, M. \& Horvathova, M. (2019). Human Factor in Industry 4.0 in Point of View Ergonomics in Slovak Republic, Proceedings of the 30th DAAAM International Symposium, pp.0284-0289, B. Katalinic (Ed.), Published by DAAAM International, ISBN 978-3-902734-22-8, ISSN 1726-9679, Vienna, Au

[4] Skrivanova, N. \& Melichar, M. (2019). The Comparison of Destructive and Non-Destructive Forms of Measurement in the Automotive Industry, Proceedings of the 30th DAAAM International Symposium, pp.0995-1002, B. Katalinic (Ed.), Published by DAAAM International, ISBN 978-3-902734- 22-8, ISSN 1726-9679, Vienna, Austria DOI: 10.2507/30th.daaam.proceedings. 138

[5] Poor, P. \& Basl, J. (2018). Czech Republic and Processes of Industry 4.0 Implementation, Proceedings of the 29th DAAAM International Symposium, pp.0454-0459, B. Katalinic (Ed.), Published by DAAAM International, ISBN 978

[6] Brkljac, M. \& Sudarevic, T. (2018). Sharing Economy and „Industry 4.0“ as the Business Environment of Millennial Generation - a Marketing Perspective, Proceedings of the 29th DAAAM International Symposium, pp.1092-1101, B. Katalinic (Ed.), Published by DAAAM International, ISBN 978- 3-902734-20-4, ISSN 1726-9679, Vienna, Austria DOI: 10.2507/29th.daaam.proceedings.156

[7] Clares Rodriguez, J. M.; Vazquez Martinez, J. M.; Gomez-Parra, A.; Puerta Morales, F. J. \& Marcos, M. (2016). Experimental Methodology for Evaluating Workpieces Surface Integrity in Dry Turning of Aerospace Alloys, Proceedings of the 26th DAAAM International Symposium, pp.0849-0855, B. Katalinic (Ed.), Published by DAAAM International, ISBN 978-3-902734- 07-5, ISSN 1726-9679, Vienna, Austria DOI:10.2507/26th.daaam.proceedings. 118

[8] Kuts, V.; Sarkans, M.; Otto, T. \& Tahemaa, T. (2017). Collaborative Work Between Human And Industrial Robot In Manufacturing By Advanced Safety Monitoring System, Proceedings of the 28th DAAAM International Symposium, pp.0996-1001, B. Katalinic (Ed.), Published by DAAAM International, ISBN 978-3-902734-11-2, ISSN 1726-9679, Vienna, Austria DOI: 10.2507/28th.daaam.proceedings.138

[9] Bicova, K[aterina]; Kutlwaser, J[an] \& Sklenicka, J[osef] (2016). Issue of High Precision Manufacturing Analysis in Automotive Industry, Proceedings of the 27th DAAAM International Symposium, pp.0353-0357, B. Katalinic (Ed.), Published by DAAAM International, ISBN 978-3-902734-08-2, ISSN 1726-9679, Vienna, Austria DOI: 10.2507/27th.daaam.proceedings.052

[10] Kubatova, D[ana] \& Melichar, M[artin] (2018). Effect of Scanning Speed when Measuring Surface Roughness, Proceedings of the 29th DAAAM International Symposium, pp.1249-1255, B. Katalinic (Ed.), Published by DAAAM International, ISBN 978-3-902734-20-4, ISSN 1726-9679, Vienna, Austria DOI: 10.2507/29th.daaam.proceedings. 180 